\title{
Ürün Adı Değişimi ile Yapılan Yeniden Markalamaya Tüketici Tepkisi: Pirina Yağı Üzerine Bir Araştırma
}

\author{
Consumer Response to Rebranding Through Product Name Change: \\ A Research on Olive Pomace Oil
}

\author{
Yrd. Doç. Dr. İsmail Tamer Toklu - Yrd. Doç. Dr. Arzu Tuygun Toklu
}

\begin{abstract}
Başvuru Tarihi: 15.06.2015
\end{abstract}
Kabul Tarihi: 08.12.2016

\section{Öz}

Yeniden markalama müşterilerin hafizasında yeni isim, slogan, logo, tasarım veya bunların bileşimi gibi yeni marka elemanlariyla yeni ve farkh bir konum oluşturmak için yapılan stratejik bir yaklaşımdır. Yeniden markalamada başarıl olmak için doğru strateji ve uygulama birlikte önemlidir. Bu araștırma ile yeniden markalama kapsamında zeytinyağı kategorisinde bir ürün olan pirina yağının adının zeytin püresi yă̆ı olarak yeniden adlandırılmasına tüketici tepkisi incelenmektedir. Oluşturulan model ile yeniden adlandırma sonrası ürün imajının, değişime yönelik tutumun, kategoriye bağhllĭgın ve ad-ürün uyumunun yeni adı kullanan markaya yönelik tüketici algisına etkisi ve sonrasinda bu alginin davranışsal niyete etkisi incelenmiştir. Araştırmanın verileri kolayda örnekleme yöntemiyle seçilen tüketicilerle yüz yüze yapilan anket çalışmasından elde edilmiştir. SmartPLS yapısal eşitlik modellemesi yöntemi ile model analiz edilmiştir. Araștırmadan elde edilen bulgulara göre; zeytin püresi yağı adının imajı pirina yağı adına göre daha yüksek bulunurken, değişime yönelik tutumun ve ad-ürün uyumunun yeni adı kullanan markaya yönelik algiyı etkilediği, bu algının da davranışsal niyeti etkilediği bulunmuştur. Çalışma ürün adının değişimini içerdiğinden akademik literatür ve tedarik zincirindeki tüm paydaşlara artı değer sunmaktadır.

Anahtar Kelimeler: Yeniden Markalama, Yeniden Adlandırma, Tüketici Algısı, Pirina Yağ

\begin{abstract}
Rebranding is a strategic approach to create a new and different position in the mind of customers with the new brand elements such as a new name, slogan, logo, design or a combination of them. This strategy and its effective application together are important for successful rebranding. This research examines the consumer response to renaming of pirina oil, a product in olive oil category, substitution to olive pomace oil under the rebranding concept. The impacts of the product image after renaming, overall attitudes towards renaming, attachment to category, fit between substitution name and the product on the perception of brand using the substitution name were investigated with a proposed model. Moreover, the impact of this brand perception on the behavioural intention was also investigated. The research data were obtained from consumers with face to face survey by using convenience sampling method. The model was analysed with SmartPLS structural equation modelling method. According to the findings of the study; the image of the name of olive pomace oil was found higher than the substitute name of pirina oil. The effects of overall attitudes towards the renaming, and fit between substitution name and the product were found significant on the perception of brand using the substitution name. This study presents added value to both academic literature because of investigating renaming a product, and all stakeholders in supply chain.
\end{abstract}

Keywords: Rebranding, Renaming, Consumer Perception, Olive Pomace Oil

Yrd. Doç. Dr. İsmail Tamer Toklu, Recep Tayyip Erdoğan Üniversitesi Findıklı Uygulamalı Bilimler Yüksekokulu, ismailtamer.toklu@erdogan.edu.tr Yrd. Doç. Dr. Arzu Tuygun Toklu, Recep Tayyip Erdoğan Üniversitesi Findıkı Uygulamalı Bilimler Yüksekokulu, arzu.tuyguntoklu@erdogan.edu.tr 


\section{Giriș}

Yeniden markalama işletmelerin markalarına yönelik olarak müşterilerin hafızalarında yeni isim, slogan, logo, tasarım veya bunların bileşimi gibi yeni marka elemanlarını uyarlayarak yeni ve farklı bir konum oluşturmak amacıyla kullanılan stratejik bir yaklaşımdır (Muzellec ve Lambkin, 2006). Marka adının değiştirilmesi bir işletme tarafından pazarlanan bir ürün veya hizmetin adının değiştirilmesidir (Muzellec ve Lambkin, 2006). Bu değişimler aracıllğı ile marka algıları, yeni marka çağrışımları ve anlamları yaratılarak, yeni marka elamanları müşterilerin hafizasinda güncellenebilir (Gotsi ve Andriopoulos, 2007). Görsel marka elemanları ve yeniden konumlandırmanın değişmesi ile pazarlamacılar müşteri tabanını genişleterek, mevcut müşterinin taleplerini arttırma ve yeni müşteriler çekmeye teşebbüs eder. Birçok uygulamacı başarılı bir yeniden markalama stratejisinin marka imajını, marka tutumunu ve marka çağrışımlarını geliştirebileceğine (Andrews ve Kim, 2007) ve tüketici kullanımını canlandırabileceğine inanmaktadır. Yeniden markalama stratejisinin artan bir şekilde kullanılmasına rağmen, marka denkliği ve marka bağlllığ üzerinde ciddi zararlara yol açabilecek çok riskli ve zor bir strateji olduğu da uygulamalardan görülmektedir (Aaker, 1991; Keller, 1993). Müşteriler değişimleri benimsemeyebilir veya yeniden markalama sonrasında çekirdek marka değerlerinin kaybolduğunu algıladıklarında, markaları tarafından aldatıldıklarını bile hissedebilirler (Haig, 2003).

Birçok çalışmada işletmelerin yeniden markalama kararının arkasındaki güdü tartışılmıştır. Markaların canlandırılması kararlarının arkasındaki birkaç neden olarak olumsuz tanıtım, kalite konuları, müşteri ihtiyaç ve tercihlerindeki değişim, rekabetçi eylem ve pazarlama çevresindeki yeni gelişmeler sayılabilir (Keller, 1999; Andrews ve Kim, 2007). Bunlardan ayrı olarak, Stuart ve Muzellec (2004) satın alma veya ayırma gibi operasyonel nedenlerden dolayı da yeniden markalamanın söz konusu olabileceğini belirtir. Yeniden markalama kararları ekonomik şartlardaki değişimlerle ilgili olabilir (Woon, 2011). Yeni bir başlangıç yapma arzusundaki yeni işletme yönetimlerinin de yeniden markalamaya yönelebildiği görülmektedir.

Mevcut markalama literatüründeki marka adının değiştirilmesine ilişkin az sayıdaki çalışma bize marka değerinin transferinde etkili olan beş temel faktörü tanımlar (Delassus ve Descotes, 2012). Bunlar marka değiştirme bilgisi (Delassus, 2005), değişime karşı tutum ya da kabul derecesi (Delassus, 2005), eski ve yeni marka arasinda algilanan benzerlik (Collange, 2008), ilk markaya olan bağlllık (Collange, 2008) ve bir şemsiye markanın varlığ (Aimé-Garnier ve Lai, 2008) olarak sıralanabilir. Bu faktörler tüketicinin değişimi kabul etmesinde dikkat edilecek hususlar olarak belirtilebilir.

Yeniden markalama son yıllarda artmasına rağmen, konuyla ilgili çok az bilimsel araştırma yapılmıştır (Collange, 2008; Muzellec ve Lambkin, 2006; Jaju vd., 2006; Aimé-Garnier ve Roux, 2006). Birkaç çalışma ile markalama stratejisinden (yani yeni marka adının seçimi) daha çok uygulama stratejilerine (yani süreç) odaklanılmıştır. Ancak, yeniden markalamanın başarılı olması için her iki stratejinin de doğru olması gerekir (Keller, 2003). Sadece iki çalışmada (Jaju vd., 2006;. Collange, 2008) iki marka özelliğinin ürün / şirketin değerlendirilmesini nasıl etkilediği araştırılmıştır.

Yeniden markalama kapsamında yapılan yeniden adlandırma büyüme firsatları sunmasına rağmen, burada temkinli bir yaklaşım önemlidir. Ad değişikliği genellikle zaman alıcı, karmaşık ve pahalıdır ve yalnızca zorlayıcı pazarlama veya mali hususlar ve uygun destekleyici bir pazarlama programı yapıldığında işletmeler bu stratejiyi izlemelidir. Kurumsal markalama stratejisi ve pazarlama hedefleri göz önüne alındığın$\mathrm{da}$, işletmeler aday marka isimlerini hatırlanabilirlik, anlamlılık, sevecenlik, korunabilirlik, uyumluluk ve aktarılabilirlik açısından değerlendirmelidir. Tüketici pazarı öncelikli hedef kitle ise, isim belirli ürün özellikleri, faydaları ya da değerleri yansıtabilir veya düşündürebilir. Uygun seçilir ve kullanılırsa, yeni adlar zamanla aşinalık ve kabul sağlarlar (Kotler ve Armstrong, 2014).

Burada Kanola yağının ürün adının değişimi analoji yapmamız için güzel bir örnektir. Kanola yağı (Canola Oil) ile ilgili Kuzey Amerikalı tüketicilerin tartışmaları incelendiğinde şu soruların karşımıza çıktığı görülmektedir. Soya yağı soyadan, ayçiçekyağı ayçiçekten, zeytinyağı zeytinden, mısıryağı mısırdan elde edilirken kanola yağının adı nereden gelmektedir? Toksik bir özelliğe sahip rapeseed yağ ortaya çıkan sorunlardan dolayı Kanadalı üreticiler tarafından başarılı bir şekilde adı değiştirilerek Ka- 
nola $($ Canola $=$ Canadian Oil, Low Acid $)$ yağı adını almıştır. Buradan hareketle bizim üzerinde çalıştığ1mız bu araştırmanın konusu olan ürün mevcut adı ile pirina yağı olan yağdır.

$\mathrm{Bu}$ araştırmanın amacı ürün adının değişimine veya zeytinyağının bir türevi olan pirina yağının varsayımsal olarak 'zeytin püresi' yağı şeklinde yeniden markalandırılmasına (yeniden adlandırılmasına) tüketici tepkisini incelemektir. İngilizce'de 'Olive Pomace Oil' olarak adlandırılan bu yağ Rumca kökenli olarak Türkçe’ye pirina yağı olarak girmiştir. Yapılan incelemeye göre, Türkiye'de farkındalık oluşturmada pirina adının olumlu bir etkisinin olmadığı görülmüştür. Türkçe bir anlam ifade etmeyen ve herhangi bir çağrışım oluşturmayan pirina adının yeniden adlandırılması ile ürünün tüketici tarafında hak ettiği konuma kısa sürede ulaşacağı düşünülmektedir.

Bu çalışma kapsamında öncelikle pirina yağı hakkında bilgi verilmekte, daha sonra yeniden markalama konusu üzerine yapılan literatürdeki çalışmalar gözden geçirilmektedir. Kavramsal çerçeve ve hipotez geliştirme ile birlikte bağımlı ve bağımsız değişkenler tanımlanarak tüketicinin bu yeni adı kullanan markaya yönelik algısı ve bu algının satın alma davranışına etkisi ölçülmektedir.

Pirina yağını pazarlama bakış açısı ile araştıran bu çalışmanın Türkiye için önemli olduğu düşünülmektedir. Yeniden markalama konusu uygulamada çok karşılaşılmasına rağmen akademik literatürde tüketici ürünleriyle ilgili sınırlı sayıda incelemenin olduğu görülmektedir. Ancak, yeniden markalamanın bir çeşidi olan ürün adının yeniden adlandırılmasını araştıran bir çalışmanın literatürde bilebildiğimiz kadarı ile olmadığı görüldügünden, çalışmanın bu anlamda da önemli olduğu söylenebilir.

\section{Kavramsal Çerçeve ve Hipotez Geliştirme}

Pirina, zeytinin yağa dönüştürülmesi işleminde elde edilen bir üründür. Yağlı ve nemli olan bu posa, işlendiği zaman hem ikincil bir yağa hem de yenilenebilir bir yakıt kaynağına dönüşür (http://pirina.data-ist. com/ erişim 8.6.2015). Diğer bir ifadeyle, pirina zeytin sektöründe tarımsal bir yan üründür; kendi doğasından dolayı, tüm zeytin üreten ülkeler için de işlenmediğinde büyük bir çevresel sorundur (Nasopoulou ve Zabetakis, 2013).
Türkiye’de yemeklik zeytinyağı Türk Standartları Enstitüsünün (TSE) TS 341 nolu standartı ve T.C. Gıda Tarım ve Hayvancılık Bakanlığı Türk Gıda Kodeksi'nin zeytinyağı ve pirina yağı tebliği ile tanımlanmaktadır. TS 341'e göre zeytinyağı, zeytin ağacının meyvelerinden TS 9591'e uygun yerlerde üretilen yağ olarak tanımlanmaktadır. Üç tane alt sınıftan bahsedilmektedir. Bunlar natürel zeytinyağ zeytinyağı ve riviera zeytinyağı şeklindedir.

Türk Gıda Kodeksi zeytinyağ nin amacı ise, "zeytinyağları ve pirina yağlarının tekniğine uygun ve hijyenik şekilde üretim, hazırlama, işleme, muhafaza, depolama, taşıma ve pazarlanmasinı sağlamak üzere özelliklerini” belirlemektir. Tebliğin 4a maddesine göre, "ham pirina yağı: pirinanın çözücülerle ekstraksiyonu veya diğer fiziksel işlemler sonucu elde edilen, reesterifikasyon işleminden geçmemiş, diğer yağlar ve karışımları ile karıştırılmamış, doğrudan tüketime uygun olmayan, rafinasyon veya teknik amaçlı kullanıma uygun yağdır”. 4b maddesine göre, "pirina yağı: rafine pirina yağı ve doğrudan tüketime uygun natürel zeytinyağları karışımından oluşan, serbest yağ asitliği oleik asit cinsinden her 100 gramda 1,0 gramdan fazla olmayan yağdır”. 4c maddesine göre, "rafine pirina yağı: ham pirina yağının doğal trigliserid yapısında değişikliğe yol açmayan yöntemlerle rafine edilmeleri sonucu elde edilen ve serbest yağ asitliği oleik asit cinsinden her 100 gramda 0,3 gramdan fazla olmayan yağdır". 4 ç maddesine göre, "zeytinyağı: sadece zeytin ağacı (Olea Europaea L.) meyvelerinden elde edilen yağlardır”. Çözücü kullanılarak ekstrakte edilen veya reesterifikasyon işlemi ile doğal trigliserid yapısı değiştirilmiş yağlar ve diğer yağlarla karışımı bu tanımın dışındadır. Aynı tebliğin 5 ç maddesi, "zeytinyağı diğer sıvı yağlara ve diğer sıvı yağlar zeytinyağına karıștırılamayacağını bildirirken”, 13 maddesi ise, "pirina yağının hiçbir koşulda zeytinyağı olarak adlandırılamayacağını” bildirmektedir.

İngilizcede ise pirina yağı 'olive pomace oil' olarak adlandırılmaktadır. Uluslararası Zeytin Konseyi standartları (IOC standard, COI/T.15/NC No 3) da Türk Gıda Kodeksine benzer şekilde tanımlamaktadır. Burada da bu yağın hiç bir şekilde zeytinyağı olarak adlandırılamayacağı belirtilmektedir (www.internationaloliveoil.org erişim 8.6.2015). Diğer taraftan, pirina adının Türkçe'ye Rumca'dan geçtiği görülmektedir. Türk Dil Kurumuna göre pirina, "zeytinin sıkıldıktan sonra yağ bakımından zenginliğini yitirmeyen, gübre veya hayvan yemi olarak kullanılan küspesi” olarak tanımlanmaktadır. 
Diğer bir ifade ile pirina yağı, zeytinlerin, mekanik olarak yağa dönüştürülmesinden sonra arta kalan katı alt ürün olan pirinadan elde edilen yağdır. $100 \mathrm{~kg}$ zeytinden ortalama 10-27 kg zeytinyağ $1,35-45 \mathrm{~kg}$ pirina; $100 \mathrm{~kg}$ pirinadan, ortalama 6-7,5 kg pirina yağ 1 , 60-70 kg kuru pirina elde edilmektedir. Kuru pirina yakıt olarak değerlendirilirken, elde edilen pirina yağ ise dünyanın aksine Türkiye'de daha çok gıda olarak ihracatı dışında sabun yapımında kullanılmaktadır (www.dogusprina.com erişim 7.6.2015). Türkiye'de yıllık pirina üretiminin yaklaşı olarak 250.000 ton olduğu belirtilmektedir (http://pirina.data-ist.com/ erişim 8.6.2015).
Pirina yağının ekonomisi incelenip zeytinyağı ile karşılaştırma yapılırsa pazardaki fiyat konumlandırması hakkında bir bilgi vereceği düşünülmektedir. Karşılaştırma için Bari (İtalya) fiyatları incelenebilir. Tablo 1'de verilen 2011 yllından 2015 yllına kadar üretici ya da rafineri çıkış fiyatları karşılaştırıldığında 5 değerin ortalamasına göre rafine pirina yağ 1 (B) yaklaşı $\mathrm{k}$ olarak \%37 oranında rafine zeytinyağından (A) daha ekonomik olduğu görülmektedir. Bu fiyat farkı yağ sektöründe herkesin şikâyet ettiği tağşişi (pahalı ürün içine ucuz ürünü karıștırma hilesi) cazip hale getirerek sektörde haksız rekabete neden olmaktadır.

Tablo 1. Bari (İtalya) Rafine Zeytinyağı ve Rafine Pirina Yağı Karşılaştırması

\begin{tabular}{|c|c|c|c|}
\hline Y11 & $\begin{array}{c}\text { Rafine zeytinyağ1 } \\
\text { fiyat } € / \text { ton (A) }\end{array}$ & $\begin{array}{c}\text { Rafine pirina yağ1 } \\
\text { fiyatı } € / \text { ton }(\mathrm{B})\end{array}$ & $\begin{array}{c}\text { Oran } \\
(\mathrm{B} / \mathrm{A})\end{array}$ \\
\hline 2011 & 1750 & 1200 & 0,686 \\
\hline 2012 & 2550 & 1700 & 0,666 \\
\hline 2013 & 2550 & 1600 & 0,627 \\
\hline 2014 & 2500 & 1500 & 0,600 \\
\hline 2015 & 2950 & 1750 & 0,593 \\
\hline Ortalama & & & 0,634 \\
\hline
\end{tabular}

Kaynak: http://www.internationaloliveoil.org/estaticos/view/133-eu-producer-prices erişim 3.6.2015

Ayçiçekyağ 1 Türkiye'de yemeklerde ve kızartmalarda en çok tercih edilen yağdır. Ekonomik olmasının ve alışkanlıkların tercihte önemli bir etken olduğu düşünülmektedir. Ancak sağlik söz konusu olduğunda zeytinyağının tüketici değerlendirmesinde önemli bir konumu vardır. $\mathrm{Bu}$ verilerden hareket eder isek zeytinyağının bir türevi olan pirina yağı ayçiçekyağına alternatif bir ürün olabilir. Farklı sıcaklıklarda ayçiçekyağına göre daha iyi bir oksitlenme stabilitesi gösterdiğinden rafine prina yağının kızartmalar için çok iyi bir seçenek olduğunu araştırmalar göstermektedir (Bulut ve Yilmaz, 2010).

Pirina yağı dünyada gıda olarak önemli bir tüketime sahip olmasına rağmen Türkiyede tağşişte kullanılmıyor ise gıda dışı olarak değerlendirilmekte ya da dökme olarak katma değeri düşük bir şekilde ihraç edilmektedir. Bu nedenle ürün adının yeniden adlandırılması bu kapsamda önemlidir. Uygun bir yeniden adlandırma ile ürünün farkındalığını ve imajını kolayca arttırmak ürüne olan talebi yükseltecektir. Bu çalışmada ürünün yeni adının 'zeytin püresi yağı' olarak yeniden adlandirılması yazarlar tarafindan önerilmektedir. Çünkü zeytin, yağa dönüştürülürken kırılıp, yoğrulup, püre haline getirildikten sonra üç faza ayrıştırılmaktadır. Pirina dünyada zeytinyağ 1 kategorisinde önemli bir bitkisel yağ çeşiti olmasına rağmen ürünün adının Türkiyede posa, küspe gibi olumsuz kelime ya da Türkçe karşıllığı olmayan pirina gibi kelimelerle ifade edilmesi ürünü hak ettiği değerden uzaklaştırmaktadır.

$\mathrm{Bu}$ bilgilerden hareketle, herhangi diğer özellikler dikkate alınmaksızın, tüketicilerin yalnızca ürünün yeniden adlandırılmasına yönelik tepkisi araştırılmıştır. Buna göre, ürün adının pirina yağı yerine zeytin püresi yağı olarak yeniden adlandırılmasıyla ilgili olarak aşağıdaki hipotezi geliştirebiliriz.

$\mathrm{H}_{1}$ : Yeniden adlandırma öncesi ürün imajı ile yeniden adlandırma sonrası ürün imajı arasında anlamlı bir fark vardır. 


\section{İmaj}

İmajı Aaker (1991) müşteriler ve diğerleri tarafından markanın nasıl algılandığı olarak tanımlar. Biel (1992)'e göre marka imajı, müşteriyi markaya bağlayan fonksiyonel ve duygusal temelli tutumların bir fonksiyonudur. Keller (2013) marka imajını tüketicinin belleğindeki marka çağrışımlarının yansıttığ 1 markayla ilgili tüketicilerin algıları olarak belirtir. Olumlu bir marka imajı pazarlama iletişiminin etkinliğini arttırabilir ve kendisine rekabet avantajı sağlayacak marka denkliğini kuvvetlendirebilir. İşletmenin pazarlama programının önemli bir kısmı marka imajı ve stratejisini sürdürebilmektir. İmaj önem yaratabilir, bilgi toplamada, markayı ayırt etmede tüketiciye yardımcı olur, satın almak için bir neden, aynı zamanda yapıcı duygular oluşturur ve marka yayma için bir temel sağlar (Aaker, 1991).

Ürün adı yeniden adlandırıldıktan sonra kategori içerisinde yeni bir ürün sınıfı olarak tanımlanıp, marka yayma olarak da değerlendirilebilir. Bir işletme yeni bir ürünü mevcut marka ile piyasaya sürerse bu marka yayma stratejisidir (Kotler ve Keller, 2012). Müșterilerin bir markayla ilgili var olan olumlu bilgi ve aşinalığı bu markanın yeni bir ürününe yönelik olumlu tutum geliştirmesine yardımcı olabilir, hatta bu yeni ürünle marka ailesinin imajı bile gelişebilir.

Aaker ve Keller (1990)'a göre, tüketiciler orijinal ve yayma yapılan ürün arasında benzerlik algılarlarsa, marka yaymayı kategoriyle ilişkilendirerek ana marka ile yayması yapılan ürünü kolayca bir araya getirebilir. Yapilan yeniden markalamanın ve marka yaymanın imajı ilgili markaya yönelik algıyı geliştirebilir. Bu bilgilerden hareket ederek aşağıdaki hipotezi geliştirebiliriz.

$\mathrm{H}_{2}$ : Yeniden adlandırma sonrası ürün imajı yeni adı kullanan markaya yönelik algıyı etkiler.

\section{Tutum}

Aaker ve Keller (1990)'a göre tutum müşterilerin toplam kalite algıları olarak kavramlaştırılabilir. Kalite tüketici tercihleri ve tatminine yardım eden en önemli ürün özelliklerinden bir tanesidir. Tüketiciler yeniden markalama stratejilerine yönelik olumlu tutumla birlikte pazarlama stratejisinin diğer yönlerini de içeren çeşitli fiziksel ve sosyal nesnelere yönelik tutuma da sahip oldukları zaman, davranışsal eylemlerle markaya yönelik olumlu davranış içinde olacak- lardır. Benzer şekilde, olumsuz tutuma sahip ve bilgi işlem sürecinde önyargılı bireyler markaya olumsuz davranacak ve bu durum da marka için bir felaket olabilecektir (Peter ve Olson, 2010).

Tutum aynı zamanda, reklam veya yeniden markalama stratejisi gibi harici bir uyarıcının etkisiyle de oluşturulabilmektedir. Aşina olunan ve yabancı markaların her ikisi için marka tutumu üzerinde önceki tutum ve reklama yönelik tutum arasında pozitif bir ilişki olduğu bulunmuştur (Edell ve Burke, 1986). Tüketicilerin tanıtım sonrası markalara yönelik tutumları ile yeniden markalama yapan markalara yönelik tutumları önceki tutumlarından etkilenmektedir.

Yeniden markalama stratejilerine yönelik tutumun nasıl oluştuğunu açıklayan 2 teori vardır. Birincisi, Bilginin Bir Araya Getirilmesi Teorisidir (Information Integration Theory). Bu teoriye göre, bireyler yeni bir bilgi elde ettiklerinde mevcut tutumlarını değiştirmez ve yeni tüm bilgileri tamamen kabul ederler (Anderson, 1981). Bunun yerine yeni bilgiler bireylerin hafızasında bir araya getirilerek, karıştırılarak ve mevcut tutum ve yeni bilginin bir araya getirilmesi ile tutum yaratılır. Böylece yeni tutum yalnızca birinden çok mevcut tutumlar ve yeni bilgilerden etkilenebilir. $\mathrm{Bu}$ teori temelinde pazarlama stratejileri iletildiğinde müşteriler pazarlama stratejilerini değerlendirme eğilimine girer ve mevcut tutumları ile birlikte elde ettikleri yeni bilgilerden etkilenerek yeni tutumları oluşturur. Bu kavramla uyumlu olarak Czellar (2003) müşterilerin marka yayma stratejilerini ana markaya yönelik tutum ile değerlendireceğini önerir. Benzer tartışma yeniden markalamaya da uyarlanabilir. Orijinal marka ve yenilenen markaya yönelik bilgi ve tutumun birlikte değerlendirilmesi söz konusudur.

Tutum oluşturmayı açıklamada kullanılan diğer bir teori ise Fishbein ve Ajzen (1975)'in Beklenti Değer Modelidir (Expectancy Value Model). Bu modele göre, bir bireyin bir nesneye yönelik bütünsel tutumu o nesneye yönelik değerlendirmelerle ilişkili sübjektif değer ve inançlarından etkilenir. Müşteriler bazı fonksiyonel gereksinimler ve istem dışı motivasyonların ürün veya hizmet tarafından karşılandığına inanıyorsa bu ürün ve hizmete yönelik olumlu tutuma sahip olacaktır.

Marka imajının, marka tutumu ve marka çağrışımlarının başarılı bir yeniden markalama ile iyi bir geliş- 
me sunduğu görülmektedir (Andrews ve Kim, 2007). Böylece marka imajı, marka çağrışımları ve marka tutumları tarafından yansıtılan müșterilerdeki marka algıları, yeniden markalamanın çıtıları üzerinde iyi bir ölçüm olarak tanımlanabilir. Ürünü yeniden adlandırmak değişim olarak tanımlandığında, yukarıda verilen bilgilerden hareket ederek aşağıdaki hipotezi geliştirebiliriz.

$\mathrm{H}_{3}$ : Değişime yönelik tutum yeni adı kullanan markaya yönelik algıyı etkiler.

\section{Bağlılık}

Collange (2008) ilk markaya olan bağlılığın etkisini incelemiştir. Marka bağlılığı, marka ile sürekli ve değişmez duygusal ilişkiyi (ayrılık acıdır) yansıtan ve ona psikolojik yakınlık ilişkisi ifade eden bir psikolojik değişken olarak tanımlanır (Lacoeuilhe, 2000). İlk markaya olan bağllık arttıkça yeniden markalamadan sonra ürün değerlendirme ve satın alma niyetinde düşüş daha fazla olmaktadır. Bağllıı müşterilerde yeniden markalamanın kabulünü azaltmaktadır. Bunun nedeni, yeni markanın niteliklerine bakılmaks1zın, duygusal olarak ilk markaya bağlı tüketicilerin mevcut markanın kayboluşuna içerlenmesi olabilir (Collange, 2015). Bunun tersi olarak, markaya bağlı olmayan tüketicilerin yeniden markalamaya olumlu bakabileceği tahmin edebilir.

Marka yayma doğrudan tüketici sadakatinden etkilenir. Müşteri ana markaya bağlı ise yeni bir ürünün başarısızlık riski azalır, marka yaymanın yapıldığı ürünün kabul edilme şansını arttırır (Thiele ve Mackay, 2001). Bu kapsamda ilk ürün adının bilinmediği bir durumda yeni ürün adının kategori ile ilişkili olması ve kategoriye olan bağlllık, bu yeni ürününün kabul şansını arttıracaktır. Bu bilgilerden hareket ederek aşağıdaki hipotezi kurabiliriz.

$\mathrm{H}_{4}$ : Kategoriye olan bağllık yeni adı kullanan markaya yönelik algıyı etkiler.

\section{Ad ve Ürün Uyumu}

Marka yaymayla ilgili tutum çalışmaları, aynı marka altında pazarlanan ürünler birbirine ne kadar çok benzer ise, değerlendirmenin o kadar daha olumlu olacağını göstermektedir. (Chakravarti vd., 1990; Martin ve Stewart, 2001). Benzer şekilde, araştırmalar yaymanın değerlendirmesinde ürün adı ve markanın birbirine yakın ve uyumlu olmasının sonuçları daha olumlu etkileyeceğini göstermektedir (Aaker ve Keller, 1990; Bottomley ve Holden, 2001; Bhat ve Reddy, 2001; Völckner ve Sattler, 2007). Bu nedenle, kullanılan kavram (benzerlik, algisal uyum veya tipiklik) ne olursa olsun, marka adı yayılan markaya (ada) yaklaştıkça, marka yaymanın değerlendirmesinde sonuç daha iyi olmaktadır. Diğer bir deyişle, yeni ad ile ürün adı ne kadar birbirine yakın ise ürün değerlendirmesi ve/veya satın alma niyeti o derece daha olumlu olacaktır. Böyle bir durumda ürün değerlendirme ve/ veya satın alma niyeti daha az derecede kötüleşecektir (Collange, 2008).

Algilanan benzerlik ana marka ve yayma yapılan kategori arasındaki ürün özelliklerinin benzerliği ve üst üste gelmesi olarak düşünülür. Aaker ve Keller (1990)'a göre, tüketiciler yayma yapılan ürün ana marka kategorisindeki önemli ürün özelliklerini paylaştığı zaman yüksek bir uyum algılayabilir. Orijinal ve yayma yapılan ürün sınıfı arasında ürün benzerlikleri arttıkça tüketicilerin marka yaymayı olumlu değerlendirmesinin cesaretlendirilebildiği bulunmuştur. Diğer araştırmalar da marka yaymadaki ürün özelliğinin benzerliği ile müşteri değerlendirmeleri ve satın alma niyeti arasında olumlu bir ilişki olduğunu göstermiştir (Chakravarti vd., 1990). Bunlar bize aşağıdaki hipotezi oluşturmamıza yardım eder.

$\mathrm{H}_{5}$ : Ad ve ürün uyumu yeni adı kullanan markaya yönelik algıyı etkiler.

\section{Markaya Yönelik Algı}

Muzellec ve Lambkin (2006) kurumsal yeniden markalama olgusunun itici güçlerini ve bunların kurumsal marka değeri üzerindeki etkilerini araştırmıştır. Bu konuda ancak birkaç çalışma tüketici açısından marka adı değişimlerini incelemektedir. Bunlardan bir tanesi olan Collange (2008) çeşitli ürün kategorilerinde (çamaşır deterjanı, duş jeli, yoğurt ve çikolata) marka değişimine yönelik olarak tüketicilerin satın alma niyetlerindeki değişimi araştırmıştır. Bu çalışmalar çağrışım ve satın alma niyetlerinin transferini de ele almakla birlikte tam marka değerinin transferine gönderme yapmaz.

Nedenleri ne olursa olsun, marka adının değiştirilmesi uygulaması işletmeler için son derece risklidir. Burada tüketiciler her zamanki ürünü tanımayabilir ya da kalitesinden șüphe edebilir, bu da satın almalarını durdurabilir (Collange, 2008). Bir markanın değişi- 
mi ile karşılaşan tüketiciler, markaya yönelik zihinsel çağrışımları, marka imajı algılarını, ürün kalitesi algılarını, farkındalık ve sadakatlerini kaybedebilir. $\mathrm{Bu}$ tüketiciler daha sonra başka bir markayı satın almayı tercih ederse, mevcut marka pazar payı ve karını kaybeder. Marka değiştirmelerin bu önemli potansiyel sonuçlarından dolayı, pazarlama yöneticilerinin eski marka değerini yeni markaya aktarmanın ve böylece marka sadakati kayıplarını en aza indirmenin yollarını bulması gerekir (Delassus ve Descotes, 2012).

Keller (1999) başarılı yeniden markalamanın müşteride markaya yönelik algıyı arttırmaya yardımcı olacağını ve tüketimi cesaretlendirebileceğini ileri sürer. Böylece yenilenen markaya yönelik müşterilerin algı ve davranışsal niyetini arttırmada yeniden markalamanın etkinliği dikkate alınabilir.

Tutumlar ve sübjektif normlar tarafindan saptanan gerçek davranışları davranışsal niyetler tahmin edebilir (Fishbein ve Ajzen, 1975). Fishbein ve Manfredo (1992) sosyal davranışların çoğunun tahmininde niyetleri önerir. Müşterilerin davranışsal niyetlerindeki değişim, yeniden markalamanın müşteriyi nasıl etkilediğini gösterir. Satın alma sıklığı ve miktarındaki artış işletmenin daha fazla kar elde etmesini sağlar.

Olumlu marka inançları, marka tercihi ve satın alma kararlarını da içeren markaya yönelik müşteri tepkilerini oluşturabilir (Keller, 1993). Cobb-Walgren vd. (1995) kuvvetli marka denkliğinin davranışsal sonucunun, müşteri algılarının ana öncüllerden birisi olabileceğini belirtir.

Birçok araştırmacı bir markaya yönelik tutum ve algıların müşterilerdeki satın alma niyetini etkileyebileceğini önerir. Hellier vd. (2003) daha iyi marka algısının müşterilerin tekrar satın alma niyetlerini arttırabileceğini deneysel destekle saptamaktadır. Buna göre aşağıdaki hipotezi kurabiliriz.

$\mathrm{H}_{6}$ : Yeni adı kullanan markaya yönelik algı davranışsal niyeti etkiler.

Literatürdeki bu bilgilere dayanarak araştırma modeli için Şekil 1 önerilmektedir.

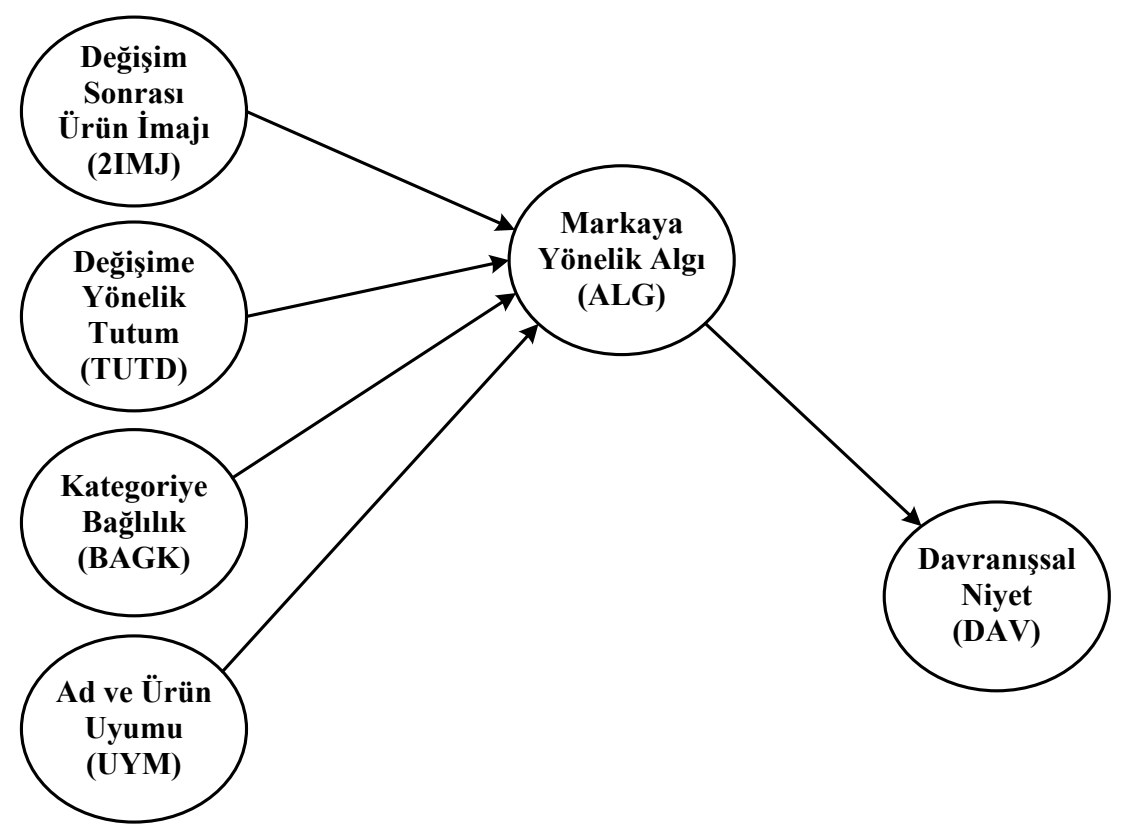

Şekil 1. Araştırma Modeli 


\section{Metodoloji}

$\mathrm{Bu}$ çalışma yeniden markalama kapsamında zeytinyağı kategorisinde bulunun, yurtdışında önemli bir ürün olmasına rağmen yurtiçinde gida dışı olarak değerlendirilen pirina yağının adının varsayımsal olarak zeytin püresi yağı şeklinde yeniden adlandırıldığında değişen tüketici algısı ve davranışlarını incelemektedir. Aşağıda anketle ilgili örneklem ve ölçekle ilgili bilgiler verilerek, kurulan teorik model için yapılan analizler açıklanmaktadır. Kurulan model SmartPLS (Kısmi En Küçük Kareler) yapısal eşitlik modellemesi kullanılarak analiz edilmiştir.

\section{Örneklem}

Araştırmanın verileri 1-10 Mayıs 2015 tarihleri arasında kolayda örnekleme yöntemi ile seçilen gönüllü tüketicilerle yüz yüze yapılan anketlerden elde edilmiştir. Anket formu hazırlanırken literatüre başvu- rularak konuyu en iyi şekilde ifade ettiği düşünülen anket soruları beşli Likert ölçeği ile (1-hiç katılmıyorum 5-tamamen katılıyorum) hazırlanmıştır. Anket hazırlandıktan sonra yapılan 6 adet ön görüşme ile soruların anlaşılırlığ test edilmiş, sonrasında gereken düzeltmeler yapılarak anket formu son şeklini almıştır. 110 anket yapılmış olmasına rağmen bunların 11 tanesi elenerek kalan 99 veri ile analizler gerçekleştirilmiştir. Eleme süreci için Hair vd. (2010)'nin önerdiği yaklaşım kullanılmıştır. Örneklemin demografik özellikleri Tablo 2'de verilmektedir. Buna göre, araştırmanın cinsiyet olarak kadınlar \%51,5'ini erkekler ise \%48,5'ini oluşmaktadır. Yaş olarak 18-34 arasındakiler \%68,7'sini, 35-44 arasindakiler \%11,1'ini ve 45-64 arasındakiler \%20,2'sini oluşturmaktadır. Mesleklerine göre ise beyaz yaka çalışanlar \%36,4'ünü, mavi yakalılar \%62,6'sını ve diğerleri ise \%1'ini oluşturmaktadır.

Tablo 2. Demografik Özellikler

\begin{tabular}{|lcc|}
\hline Demografik özellikler & & $\%$ \\
\hline Cinsiyet & Kadın & 51,5 \\
& Erkek & 48,5 \\
& Toplam & 100,0 \\
\hline Yaş & $18-34$ & 68,7 \\
& $35-44$ & 11,1 \\
& $45-64$ & 20,2 \\
& Toplam & 100,0 \\
\hline Meslek & Beyaz yaka & 36,4 \\
& Mavi yaka & 62,6 \\
& Diğer & 1,0 \\
& Toplam & 100,0 \\
\hline
\end{tabular}

\section{Ölçekler}

Araştırmanın değişkenleri için literatürde daha önce güvenilirlik ve geçerliliği kabul edilen ölçeklerden istifade edilmiştir. Tüketicinin yeniden markalamaya yönelik tutumunu ölçmek için MacKenzie, Lutz ve Belch (1986) ve Mitchell (1986)'in çalışmalarından uyarlanan 4 maddeli ölçek kullanılmıştır. Yeniden markalama sonrası markaya yönelik algıların ölçümünde Andrews ve Kim (2007) tarafından geliştirilen ölçeğin uyarlanması ile elde edilen ve 9 maddeden oluşan ölçek kullanılmıştır. Davranışsal niyetin ölçümünde Cronin, Brady ve Hult (2000) tarafından geliştirilen ölçeğin uyarlanması ile elde edilen 4 maddeli ölçek kullanılmıştır. Müşterinin kategoriye bağl1lığının ölçümünde Lacoeuilhe (2000) tarafından kul- lanılan ölçeğin uyarlanması ile elde edilen 5 maddeli ölçek kullanılmıştır. Ürüne verilen yeni adın ürün ile uyumunu ölçmede Keller ve Aaker (1992) tarafından kullanılan 2 maddeli ölçekten yararlanılmıştır. İmaj ile ilgili olarak Collange (2008) ile Martin ve Brown (1991)'ın kullandığı 2 maddeli ölçekten yararlanılmıştır.

\section{Analiz ve Sonuçlar}

Verilerin analizinde SPSS v21 paket programı ve SmartPLS Yapısal Eşitlik Modellemesi kullanılmıştır. PLS’nin özellikle düşük sayıdaki örnekleme sahip araştırmalar için iyi sonuçlar verdiği bilinmektedir. PLS yol modelini tahmin etmede ihtiyaç duyulan 
en az örneklem sayısı için "en az on katı kuralı" nın karșlanması gerekir (Hair vd., 2014). Bu kurala göre, modeldeki maksimum ok sayısını işaret eden gizil değișken referans alınır. Bu değișkendeki ok sayısının 10 katı araştırma için gereken minimum örneklem sayısını gösterir. Burada Markaya Yönelik Algı (ALG) değişkeni 4 ok ile en fazla oka sahiptir. Bu kurala göre, $40\left(=4^{\star} 10\right)$ PLS yol modelini tahmin etmede olması gereken en az örneklem sayısını gösterir. Buna göre araştırmadaki 99 örneklemin yeterli olduğu tespit edilebilir.

\section{Verilerin Analizi}

Yeniden markalama kapsamında yapılan işlem öncelikle ürünün adının değiştirilmesidir. Ürünün ilk (orijinal) adı pirina yağı olarak tanımlanmakta, yeni adının ise zeytin püresi yağı olarak değiştirilmesi önerilmektedir. Aynı tüketici için iki ayrı anket uygulanmıştır. Senaryo kapsamında ilk önce ürünün orijinal adı ile anket yapılmış, daha sonra ürünün diğer özellikleri aynı kalmak koşulu ile sadece adı varsayımsal olarak değiştirilerek yenilenen ad ile ikinci anket uygulanmıştır.

Katılımcılar pirina yağı adının imajınını 2,44 ortalama ve 0,92 standart sapmayla değerlendirirken, zeytin püresi yağı adının imajını 3,72 ortalama ve 0,92 standart sapmayla değerlendirmişlerdir. Eşleştirilmiş $\mathrm{T}$ testi sonucuna göre aralarındaki farklılık $(\mathrm{t}=$ -11,252; $\mathrm{p}<0,0001)$ istatistiksel olarak anlamlı olduğundan $\mathrm{H}_{1}$ hipotezinin desteklendiği görülmektedir. Buna göre ortalaması daha yüksek olan zeytin püresi yağının imajı pirina yağına göre daha yüksektir.

Modeldeki yapıların geçerliliği ve aralarındaki ilişkilerin analizinde SmartPLS kullanılmıştır. PLS ile karmaşık modelleri ve çok sayıda maddeye sahip yapıları, doğrudan ya da dolaylı olarak analiz etmek mümkündür. Bununla birlikte PLS az sayıdaki örneklem sayısı ile baş edebilir ve verilerde istenen çok değişkenli homojenlik ve normallik gereksinimlerine de ihtiyaç duymaz (Hair vd., 2014). PLS temel bileşenler analizi ve regresyonu temel alırken, modeldeki yap1ların değişimini açılamayı amaçlar (Chin, 1998).

\section{PLS Ölçüm Modeli}

Ölçüm modelinin yani yol modelinin genel kalitesini belirlemede ölçüm modelinin kalitesi, yapısal modelin kalitesi ve yapısal modelde kullanılan her bir yapının regresyon denklemi olmak üzere üç seviye bulunur (Tenenhaus vd., 2005).
Ölçüm modelinin kalitesini belirlemek için modeldeki yapıların yakınsak (convergent) ve ayrışma (discriminant) geçerlilik ölçümleri ile her bir madde ve ölçek güvenilirliğinin değerlendirilmesi gerekir. Faktörlerin güvenilirliği için gizil (latent) yapıların faktör yükleri kontrol edilir. Bu aşamada faktörlerin modelde tutulabilmesinde tavsiye edilen kriter minimum 0,50 değeridir (Hulland, 1999).

PLS modeli ölçüm modelinin değerlendirilmesi ve yapısal modelin değerlendirilmesi olmak üzere iki aşama kullanılarak analiz edilir. Ölçüm modelinde açık değişkenler (gözlenen maddeler) ile gizil değişkenler arasındaki var olan ilişkiler değerlendirilir ve burada modeldeki yapının geçerlilik ve güvenilirliği test edilir. Güvenilir ve geçerli olan yapılar genel modeldeki ilişkileri değerlendirmede kullanılır (Hulland, 1999). Diğer taraftan yapisal model gizil yapılar arasındaki ilişkileri gösterir. Modeldeki yol katsayıları ise modelin öngörü yeteneğinin birer göstergeleridir.

Yapı geçerliliği (construct validity) ölçümde kullanılan maddelerin yapı ile ne kadar iyi bir ilişkiye sahip olduğunu gösterir. Yapı geçerliliğinin tespit edilmesinde yakınsak ve ayrışma geçerlilikleri kullanılır. Yakınsak geçerlilik için madde güvenilirliği (item reliability), kompozit güvenilirlik (composite reliability) ve açıklanan ortalama varyans (AVE: average variance extracted) olmak üzere üç kriter kullanılır.

\section{PLS Ölçüm Modeli Sonuçları}

Yukarıda ifade edilen bilgiler kullanılarak madde yükleriyle yapının güvenilirliği belirlendi. 0,50 ya da daha üzeri yükler genellikle yeterli madde güvenilirliğine işaret eder. Araştırmayı daha güvenilir yapmak için 0,70 ve daha az yüke sahip maddelerin analizden çıkarılması gerekir. Bu nedenle ALG5, ALG8 ve ALG9 maddeleri analizden çıkarılmıştır. Yapıların madde yükleri Tablo 3'de gösterilmektedir. Non parametrik bir işlem olan PLS için anlamlılık testinde T testi kullanılmış ve sonucunda yapının anlamlı olduğu bulunmuştur.

Dış yüklerin karesi alınarak madde güvenilirliği (indicator reliability) hesaplanmıştır. Burada tercih edilen eşik değer 0,70 ve üzeridir. Ancak, keşifsel bir araştırmada (explarotory research) 0,40 eşik değeri ve bunun üzeri de kabul edilebilir (Hulland, 1999). $\mathrm{Bu}$ araştırmada değerler 0,529 ile 0,933 arasında değişmektedir. Buradan hareketle modeldeki her bir maddenin değeri 0,50 değerinden yüksek olduğu için modelin güvenilirliği teyit edilmiştir. 
Tablo 3. Yapılar İ̧in Madde Yükleri

\begin{tabular}{|c|c|c|}
\hline Yap1 & Maddeler & Yük \\
\hline \multicolumn{3}{|c|}{ Değişim sonrası ürün imajı (2IMJ) } \\
\hline 1 & Zeytin Püresi yağı hakkında iyi düșüncelere sahibim & 0,966 \\
\hline 2 & Zeytin Püresi yağı hakkında olumsuzdan daha cok olumlu fikirlere sahibim & 0,966 \\
\hline \multicolumn{3}{|c|}{ Değişime yönelik tutum (TUTD) } \\
\hline 1 & Çok sevdim & 0,899 \\
\hline 2 & Çok beğendim & 0,919 \\
\hline 3 & Çok olumlu & 0,931 \\
\hline 4 & Cok ilgimi ceker & 0,893 \\
\hline \multicolumn{3}{|c|}{ Kategoriye bağlilık (BAGK) } \\
\hline 1 & Zeytinyağı kategorisi ile büyük bir duygusal bağa sahibim & 0,886 \\
\hline 2 & $\begin{array}{l}\text { Bitkisel yağlardan zeytinyağı kategorisi bir ürünü satın almak bana büyük bir } \\
\text { mutluluk verir }\end{array}$ & 0,915 \\
\hline 3 & $\begin{array}{l}\text { Zeytinyağı kategorisinden ürün satın almak veya ona sahip olmak beni iyi } \\
\text { hissettiriyor }\end{array}$ & 0,893 \\
\hline 4 & Zeytinyağı kategorisi ile yakın bağım var & 0,784 \\
\hline 5 & Zeytinyağı kategorisi beni kendine çeker & 0,871 \\
\hline \multicolumn{3}{|c|}{ Ad ve ürün uyumu (UYM) } \\
\hline 1 & Zeytin Püresi yağı, zeytinyağı kategorisinde iyi olabilecek bir yağdır & 0,940 \\
\hline 2 & Zeytin Püresi yağı, zeytinyağı kategorisine uyan bir isimdir & 0,955 \\
\hline \multicolumn{3}{|c|}{ Yeni ürün adını kullanan markaya yönelik algı (ALG) } \\
\hline 1 & $\mathrm{Bu}$ isimli ürüne sahip bir marka öncesine göre daha ihtişamlıdır & 0,727 \\
\hline 2 & Bu isime sahip marka önce olduğundan daha kuvvetli bir imaja sahiptir & 0,739 \\
\hline 3 & Zaman içinde bu isime sahip markanın imajı yükselir & 0,872 \\
\hline 4 & $\mathrm{Bu}$ isimli markanın öncekinden daha iyi olduğunu düşünüyorum & 0,883 \\
\hline 5 & 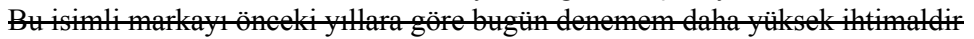 & 0,627 \\
\hline 6 & Bu isime sahip markayı öncekine göre daha çok beğendiğimi düşünüyorum & 0,813 \\
\hline 7 & $\mathrm{Bu}$ isimli marka bana öncekinden daha fazla kişilik sunuyor & 0,735 \\
\hline 8 & Buisimesahip makkäncekinden daha fazla ilginç & 0,647 \\
\hline 9 & 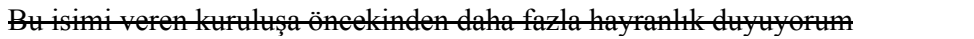 & 0,669 \\
\hline \multicolumn{3}{|c|}{ Davranışsal niyet (DAV) } \\
\hline 1 & $\begin{array}{l}\text { Ürününü Zeytin Püresi yağı olarak adlandıran markayı satın alma ihtimalim } \\
\text { yüksektir }\end{array}$ & 0,881 \\
\hline 2 & $\begin{array}{l}\text { Ürününü Zeytin Püresi yağı olarak adlandıran markayı bir arkadaşıma tavsiye } \\
\text { etme ihtimalim yüksektir }\end{array}$ & 0,905 \\
\hline 3 & $\begin{array}{l}\text { Ürününü Zeytin Püresi yağı olarak adlandıran markayı daha sık satın alma } \\
\text { ihtimalim yüksektir }\end{array}$ & 0,923 \\
\hline 4 & $\begin{array}{l}\text { Her bir alışverişte ürününü Zeytin Püresi yağı olarak adlandıran markayı daha } \\
\text { fazla satın alma ihtimalim yüksektir }\end{array}$ & 0,885 \\
\hline
\end{tabular}

Sosyal bilimlerde Cronbach's alfa değeri genel olarak içsel uyum güvenilirliğini (internal consistency reliability) ölçmek için kullanılır ve 0,70'in üzerindeki değerler yeterli olduğunu ifade eder. Cronbach's alfa aynı zamanda kompozit güvenilirlik için bir kanıt oluşturur. Fakat literatür komposit güvenilirliğin (composite reliability) Cronbach's alfa yerine kullanımını önermektedir (Bagozzi ve Yi, 1988; Hair vd., 2012). Araştırma modelinin tüm yapıları için kompozit güvenirlik 0,912 ile 0,965 , tüm Cronbach's alfa değerleri de 0,884 ile 0,931 arasında değişmektedir. Bu değerler modeldeki yapıların yeterli olduğu teyit eder.
AVE, bir yapının ölçüm hatasına bağlı olarak kendi maddelerinin göreli varyans miktarı aracılı̆̆ıla elde ettiği varyans miktarını temsil etmektedir. Yakınsak geçerliliğinin kontrolünde her bir gizil değişkenin AVE değerleri incelenir. Araştırma modelindeki AVE değerlerinin 0,636 ile 0,933 arasında değiştiği görülmektedir. AVE için eşik değer 0,50 ve üzeri olduğundan modelin yakınsak geçerliliği kabul edilir. Tablo 4'de verilen madde güvenilirliği, kompozit güvenilirlik ve AVE değerleri tüm yapıların yakınsak geçerliliğinin sağlandığını göstermektedir. 
Tablo 4. Ölçüm Modelinin Değerlendirilmesi

\begin{tabular}{|c|c|c|c|c|c|c|}
\hline $\begin{array}{l}\text { Gizil } \\
\text { Değişken }\end{array}$ & Maddeler & Yükler & $\begin{array}{c}\text { Madde } \\
\text { Güvenilirliği }\end{array}$ & $\begin{array}{c}\text { Cronbach's } \\
\text { alpha }\end{array}$ & $\begin{array}{c}\text { Kompozit } \\
\text { Güvenilirlik }\end{array}$ & AVE \\
\hline \multirow[t]{2}{*}{ 2IMJ } & 2IMJ1 & 0,966 & 0,933 & \multirow[t]{2}{*}{0,928} & \multirow[t]{2}{*}{0,965} & \multirow[t]{2}{*}{0,933} \\
\hline & 2 IMJ2 & 0,966 & 0,933 & & & \\
\hline \multirow[t]{4}{*}{ TUTD } & TUTD1 & 0,899 & 0,808 & \multirow[t]{4}{*}{0,931} & \multirow[t]{4}{*}{0,951} & \multirow[t]{4}{*}{0,829} \\
\hline & TUTD2 & 0,919 & 0,845 & & & \\
\hline & TUTD3 & 0,931 & 0,867 & & & \\
\hline & TUTD4 & 0,893 & 0,797 & & & \\
\hline \multirow[t]{5}{*}{ BAGK } & BAGK1 & 0,886 & 0,785 & \multirow[t]{5}{*}{0,927} & \multirow[t]{5}{*}{0,940} & \multirow[t]{5}{*}{0,759} \\
\hline & BAGK2 & 0,915 & 0,837 & & & \\
\hline & BAGK3 & 0,893 & 0,797 & & & \\
\hline & BAGK4 & 0,784 & 0,615 & & & \\
\hline & BAGK5 & 0,871 & 0,759 & & & \\
\hline \multirow[t]{2}{*}{ UYM } & UYM1 & 0,940 & 0,884 & \multirow[t]{2}{*}{0,886} & \multirow[t]{2}{*}{0,946} & \multirow[t]{2}{*}{0,897} \\
\hline & UYM2 & 0,955 & 0,912 & & & \\
\hline \multirow[t]{6}{*}{$\overline{\mathrm{ALG}}$} & ALG1 & 0,727 & 0,529 & \multirow[t]{6}{*}{0,884} & \multirow[t]{6}{*}{0,912} & \multirow[t]{6}{*}{0,636} \\
\hline & ALG2 & 0,739 & 0,546 & & & \\
\hline & ALG3 & 0,872 & 0,760 & & & \\
\hline & ALG4 & 0,883 & 0,780 & & & \\
\hline & ALG6 & 0,813 & 0,661 & & & \\
\hline & ALG7 & 0,735 & 0,540 & & & \\
\hline \multirow[t]{4}{*}{$\overline{D A V}$} & DAV1 & 0,881 & 0,776 & \multirow[t]{4}{*}{0,920} & \multirow[t]{4}{*}{0,944} & \multirow[t]{4}{*}{0,808} \\
\hline & DAV2 & 0,905 & 0,819 & & & \\
\hline & DAV3 & 0,923 & 0,852 & & & \\
\hline & DAV4 & 0,885 & 0,783 & & & \\
\hline
\end{tabular}

Diğer taraftan ayrışma geçerliliğinin kontrolünde iki test kullanılmaktadır. 1 - Herbir madde yükünün çapraz yüklerle karşılaştırılması ve yapının açıklanan varyansı ile paylaşılan varyansının karşılaştırılmasıdır. Burada, tasarlanan her maddenin yükünün diğer yapıların yükünden daha yüksek olması gerekir (Gefen ve Straub, 2003). 2 - Bir yapının açıllanan varyansı veya yapı ve onun maddeleri arasındaki ortak varyans, yapı ve diğer yapılar arasındaki ortak varyanstan daha büyük olmalıdır. Bu, yapının ortalama açıklanan varyansının (AVE) karekökünün diğer yapılarla karşılaştırılmasıyla ölçülür. Her bir yapı için, AVE’nin karekökünün diğer yapılarla korelasyonundan çok daha büyük olduğu bulunmuştur. Bu sonuçlara göre modeldeki yapılar yeterli ayrışma geçerliliğine sahiptir.
Burada Cronbach's alfaya ek olarak, her bir değişkenin güvenilirliği Fornell ve Larcker (1981)'in kompozit güvenilirlik ölçümü ile değerlendirilmiştir. $\mathrm{Bu}$, ilgili göstergeler tarafından paylaşılan varyansın daha iyi bir tahminini sunduğundan Cronbach's alfaya tercih edildiği belirtilmektedir.

Fornell ve Larcker (1981)'in kılavuzu ile uyumlu bir şekilde her bir ölçümün AVE değerleri 0,50 değerini aşmaktadır. Tablo 5 her bir ölçeğin ayrışma geçerliği sonuçlarını vermektedir. Matrisin çaprazındaki koyu renkli değerler $\sqrt{ }$ AVE' yi ifade eder. Tüm seçeneklerde bu çapraz değerler satır ve sütunundaki diğer değerlerden daha yüksek olduğu için ölçeğin ayrışma geçerliliği teyit edilmiş olur. Tablo 5 tüm bu gizil değişkenlerin bu şartı sağladığını göstermektedir. 
Tablo 5. Ayrışma Geçerliliğinin Kontrolï Için Fornell-Larcker Kriter Analizi

\begin{tabular}{|l|c|c|c|c|c|c|c|}
\hline \multicolumn{9}{c}{ Gizil değişken korelasyonları } \\
(LVC=Latent Variable Correlations) & \multicolumn{4}{c|}{ Ayrışma geçerliliği sağlanıyor } \\
\hline & 2IMJ & ALG & BAGK & DAV & TUTD & UYM & \\
\hline 2IMJ & $\mathbf{0 , 9 6 6}$ & & & & & & Evet \\
\hline ALG & 0,729 & $\mathbf{0 , 7 9 7}$ & & & & & Evet \\
\hline BAGK & 0,097 & 0,221 & $\mathbf{0 , 8 7 1}$ & & & & Evet \\
\hline DAV & 0,815 & 0,749 & 0,142 & $\mathbf{0 , 8 9 9}$ & & & Evet \\
\hline TUTD & 0,758 & 0,781 & 0,182 & 0,729 & $\mathbf{0 , 9 1 1}$ & & Evet \\
\hline UYM & 0,692 & 0,676 & 0,096 & 0,699 & 0,609 & $\mathbf{0 , 9 4 7}$ & Evet \\
\hline
\end{tabular}

\section{PLS Yapısal Model Sonuçları}

Yapısal modelin genel açıklayıcı gücü için bağımsız değişkenlerce açıklanan varyans miktarı ve hipotezlerin yol üzerindeki büyüklüğü ve gücü araştırılmıştır. Modelin açıklayıcılığını ölçmede regresyon analizinde de kullanıldığı gibi $\mathrm{R}^{2}$ değeri kullanılır. Buna göre 'Değişim Sonrası Ürün İmajı' (2IMJ), 'Değişime Yönelik Tutum' (TUTD), 'Kategoriye Bağllık' (BAGK) ve 'Ad ve Ürün Uyumu' (UYM) 'Markaya Yönelik Algidaki' (ALG) değişimi $\left(R^{2}=0,694\right)$;'Markaya Yönelik Algının' (ALG) da 'Davranışsal Niyeti' (DAV) $\left(\mathrm{R}^{2}=\right.$ $0,561)$ güçlü şekilde açıkladığı görülmektedir. Analiz sonucu yapısal modelin yeterli açıklayıcı güce sahip olduğunu göstermektedir.

Modeldeki yolların/ilişkilerin istatistiksel anlamlılığını ölçmek için T-İstatistiği uygulanmıştır. Yapıyı oluşturan her bir maddenin faktör yüklerinin yüksek bir şekilde anlamlı olduğu görülmektedir $(\mathrm{p}<0,0001)$.
T-İstatistiği sonuçlarına göre, 'Değişim Sonrası Ürün İmajı' (2IMJ) ile 'Markaya Yönelik Algının' (ALG) arasındaki yol $(\mathrm{t}=1,839 ; \mathrm{p}=0,067)$ anlamsiz olduğundan $\mathrm{H}_{2}$ hipotezi desteklenmemiştir. 'Değişime Yönelik Tutum' (TUTD) ile 'Markaya Yönelik Algı' (ALG) arasindaki yol $(\mathrm{t}=4,286 ; \mathrm{p}<0,0001)$ anlaml olduğundan $\mathrm{H}_{3}$ hipotezinin desteklendiği görülmektedir. 'Kategoriye Bağlllık' (BAGK) ile 'Markaya Yönelik Algının' (ALG) arasındaki yol $(\mathrm{t}=1,118 ; \mathrm{p}=$ $0,264)$ anlamsiz olduğundan $\mathrm{H}_{4}$ hipotezi desteklenmemiştir. 'Ad ve Ürün Uyumu' (UYM) ile 'Markaya Yönelik Algi' (ALG) arasındaki yol ( $\mathrm{t}=2,210$; $\mathrm{p}<$ $0,028)$ anlamlı olduğundan $\mathrm{H}_{5}$ hipotezinin desteklendiği görülmektedir. 'Markaya Yönelik Algı' (ALG) ile 'Davranışsal Niyet' (DAV) arasındaki yol ( $\mathrm{t}=1,989$; $\mathrm{p}$ $<0,047)$ anlamlı olduğundan $\mathrm{H}_{6}$ hipotezinin de desteklendiği görülmektedir. T-İstatistiği sonuçları Tablo 6 da özet olarak gösterilmektedir.

Tablo 6. Yol Katsayılarının T-istatistikleri

\begin{tabular}{|l|c|c|c|c|c|}
\hline & Std $\beta$ & $\begin{array}{c}\text { Örnek } \\
\text { Ortalamas } 1\end{array}$ & $\begin{array}{c}\text { Standart } \\
\text { Hata }\end{array}$ & T İstatistiği & p değerleri \\
\hline 2IMJ $\rightarrow$ ALG & 0,196 & 0,181 & 0,121 & 1,621 & 0,106 \\
\hline TUTD $\rightarrow$ ALG & 0,464 & 0,453 & 0,110 & 4,230 & 0,000 \\
\hline BAGK $\rightarrow$ ALG & 0,094 & 0,098 & 0,077 & 1,214 & 0,225 \\
\hline UYM $\rightarrow$ ALG & 0,249 & 0,266 & 0,103 & 2,412 & 0,016 \\
\hline ALG $\rightarrow$ DAV & 0,749 & 0,750 & 0,059 & 12,707 & 0,000 \\
\hline
\end{tabular}

Buna göre revize edilen model aşağıda verilmektedir. Şekil 2 yapısal model sonuçlarını etkilerle birlikte göstermektedir.
Aşağıdaki Tablo 7 ise hipotez, bulgu ve sonuç olarak desteklenip desteklenmediklerini özet olarak vermektedir. 


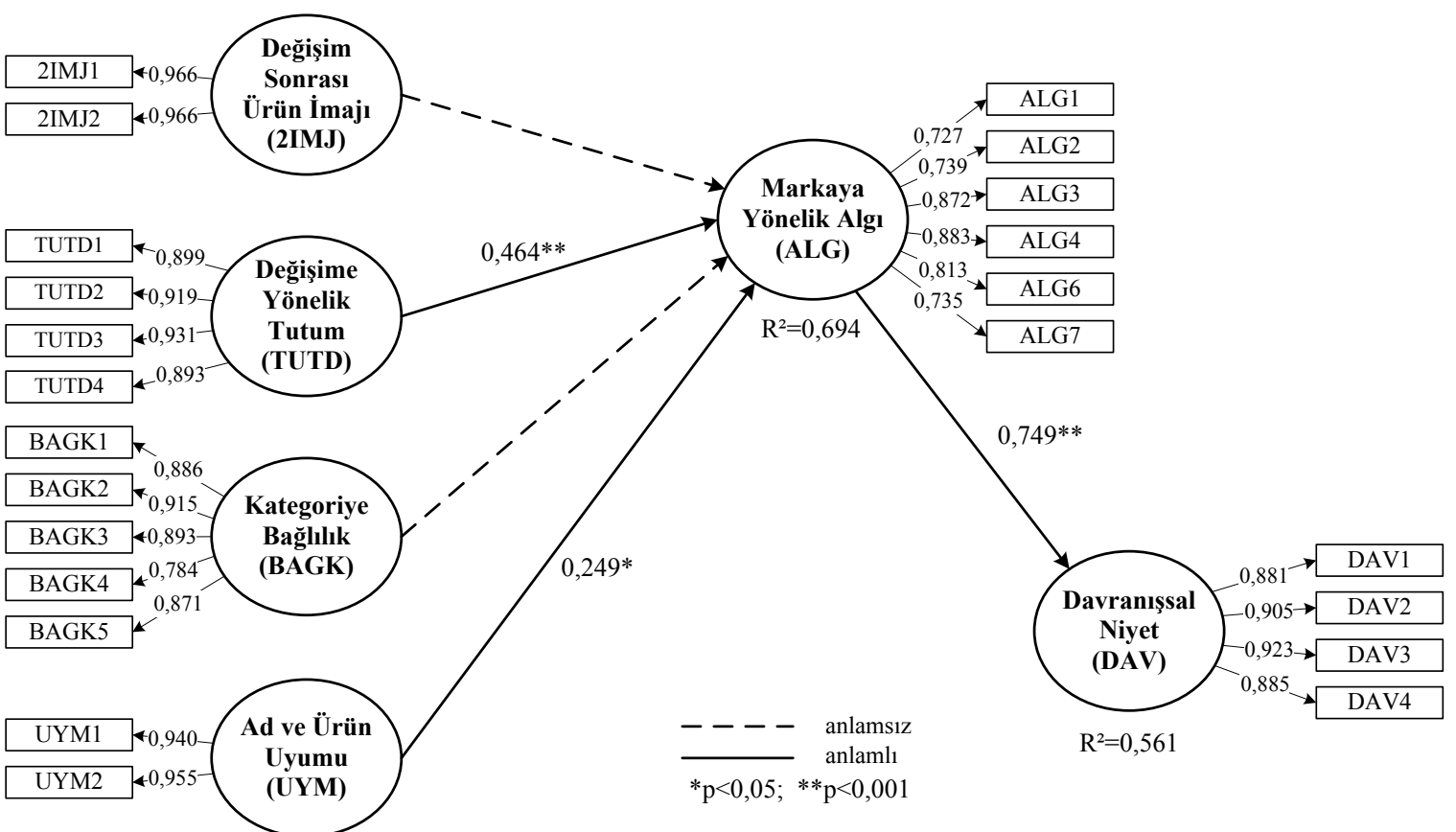

Şekil 2. Yapısal Model Sonuçları

Tablo 7. Hipotez Sonuçları

\begin{tabular}{|l|c|c|}
\hline Hipotez & Bulgu & Sonuç \\
\hline $\begin{array}{l}\mathrm{H}_{1}: \text { Yeniden adlandırma öncesi ürün imajı ile yeniden } \\
\text { adlandırma sonrası ürün imajı arasında anlamlı bir fark } \\
\text { vardır. }\end{array}$ & $\begin{array}{c}\mathrm{t}=-11,252 ; \mathrm{p}< \\
0,0001\end{array}$ & Desteklendi \\
\hline $\begin{array}{l}\mathrm{H}_{2}: \text { Yeniden adlandırma sonrası ürün imajı yeni adı kullanan } \\
\text { markaya yönelik algıyı etkiler. }\end{array}$ & $\mathrm{t}=1,839 ; \mathrm{p}=0,067$ & Desteklenmedi \\
\hline $\begin{array}{l}\mathrm{H}_{3}: \text { Değişime yönelik tutum yeni adı kullanan markaya } \\
\text { yönelik algıyı etkiler. }\end{array}$ & $\mathrm{t}=4,286 ; \mathrm{p}<0,0001$ & Desteklendi \\
\hline $\begin{array}{l}\mathrm{H}_{4}: \text { Kategoriye olan bağlılık yeni adı kullanan markaya } \\
\text { yönelik algıyı etkiler. }\end{array}$ & $\mathrm{t}=1,118 ; \mathrm{p}=0,264$ & Desteklenmedi \\
\hline $\begin{array}{l}\mathrm{H}_{5}: \text { Ad ve ürün uyumu yeni adı kullanan markaya yönelik } \\
\text { algıyı etkiler. }\end{array}$ & $(\mathrm{t}=2,210 ; \mathrm{p}<0,028$ & Desteklendi \\
\hline $\begin{array}{l}\mathrm{H}_{6}: \text { Yeni adı kullanan markaya yönelik algı davranışsal niyeti } \\
\text { etkiler. }\end{array}$ & $\mathrm{t}=1,989 ; \mathrm{p}<0,047$ & Desteklendi \\
\hline
\end{tabular}

\section{Sonuç ve Öneriler}

Yeniden markalama müşterilerin hafızasında yeni isim, slogan, logo, tasarım veya bunların bileşimi gibi yeni marka elemanlarıyla yeni ve farklı bir konum oluşturmak için yapılan stratejik bir yaklaşım şeklinde tanımlanır. Yeniden markalamanın başarısında doğru stratejilerin oluşturulmasının yanında bu stra- tejilerin doğru uygulamasının da önemi büyüktür. $\mathrm{Bu}$ araştırmada zeytinyağının bir türevi olan pirina yağı yeniden markalama bakış açısı ile incelenmiştir. Rumca olan pirina kelimesinin Türkçe karşılığının olmadığı ve Türkçe konuşan insanlar için bir anlamının bulunmadığı yaptığımız araştırma ile anlaşılmıştır. Ürüne hak ettiği değerinin verilebilmesi için 
bu çalışma ile "pirina yağı" nın "zeytin püresi yağı" olarak yeniden adlandırılması araştırmacılar tarafından önerilmiştir.

Önerilen bu ada (zeytin püresi yağı) tüketici tepkisinin incelendiği bu çalışma için oluşturulan modelle yeniden adlandırma (değişim) sonrası ürün imajının, yeniden adlandırmaya yönelik tutumun, kategoriye bağlllık ile ad ve ürün uyumunun yeniden adlandırmayı (değişimi) yapan ve/veya bu yeni adı ürünlerinde kullanan markaya yönelik tüketici algısına etkisi ve sonrasında bu markaya yönelik algının davranışsal niyete etkisi incelenmiştir. Araştırmadan elde edilen bulgulara göre; zeytin püresi yağı adının imajı pirina yağına göre daha yüksek bulunurken, yeniden adlandırmaya yönelik tutumun değişimi yapan ve/ veya bu yeni adı kullanan markaya yönelik algıyı etkilediği bulunmuştur. İlave olarak, ad ve ürün uyumunun değişimi yapan ve /veya bu yeni adı kullanan markaya yönelik algıyı etkilediği, markaya yönelik bu algının da davranışsal niyeti etkilediği bulunmuştur. Elde edilen bu bulgular yeniden markalama literatür ile uyumludur (Collange, 2008; Keller, 1999; CobbWalgren vd., 1995; Aaker ve Kotler, 1990; Anderson, 1981).

Diğer yandan yeniden adlandırma sonrası ürün imajının ve kategoriye olan bağlılığın bu adı kullanan markaya yönelik algıya olan etkisi istatistiksel olarak anlamlı bulunmamıştır. Bunda yeni adın yeterince bilinmemesi nedeniyle duygusal ve fonksiyonel bağll11ğın eksik olması etkili olabilir. Diğer taraftan müşteri ana markaya bağlı ise yeni bir ürünün başarısızlık riski azalır, ürünün kabul şansı artar (Thiele ve Mackay, 2001). Ancak, duygusal olarak ilk markaya olan bağlllık yüksek ise yeniden markalamanın kabulü azalabilir (Colllange, 2015). Burada elde edilen sonuca göre müşterilerin kategoriye bağllı̆ğı düşük olabilir. Bunun için etkin bir farkındalık çalışması ile sağlanacak daha iyi bir imaj ve ad-ürün uyumunun bu yeni ürün adını kullanan markaya olan algıyı etkileyeceği düşünülmektedir. Ürünün yeniden adlandırılması bir yeniden markalama olduğundan zeytinyağ risinde faaliyet gösteren markalar için bu uygulama aynı zamanda bir marka yayma uygulamasıdır. Son yıllarda bitkisel yağ sektöründe faaliyet gösteren işletmelerin Türkiyedeki tüketiciler için yeni tür yağlarla (Örneğin, yüksek oleik asitli ayçiçekyağı, bitkisel karışım sıvı yağ, soya yağı, kanola yağı, kızartma yağı vs.) marka yayması yaptıkları görülmektedir.
Pirina yağının yeniden adlandırılması tüm paydaşlar için büyük bir öneme sahiptir. Bu yağ ile ilgili olarak özellikle sağlık ve ekonomiklik ön plana çımaktadır. Ürünün yeniden adlandırılması ile Türkiye'de sadece gıda dışı olarak kullanılan bu ürünün katma değeri daha yüksek yemeklik yağ olarak ülke içinde kullanımının önü açılabilir. Zeytinyağının sağlıkla olan ilişkisi nedeniyle zeytin püresi yağı adının pirina yağına göre tüketici tarafından daha fazla tercih nedeni olabileceği bu araştırma ile bulunmuştur. Pirina yağı gida güvenliğini dikkate alan tüketicilerin tutum oluşturmasında ve satın alma tercihinde (Ustaahmetoğlu ve Toklu, 2015) önemli konuma sahip bir yağdır. Aynı zamanda, yapılan ortalama hesaplamalara göre rafine zeytin püresi yağ 1 rafine zeytinyağından yaklaşık olarak \%37 oranında daha ekonomiktir. Bu tedarik zinciri için ilave bir katma değeri ifade etmektedir. Bu tek başına bile önemli bir rekabet üstünlüğüdür.

İlave olarak, kalite açısından rafine zeytin püresi yağının yemeklik ve kızartmalık olarak ayçiçekyağından daha iyi bir yağ olması nedeniyle ayçiçekyağına alternatif yerli bir yağ olarak doğru pazarlama stratejileriyle pazarda hak ettiği yeri kısa sürede alması muhtemeldir. Ürün raflarda fiyat olarak zeytinyağ1nın altında ayçiçekyağının üzerinde rahatlıkla konumlandırılabilir.

Türkiye'nin ithalat kalemleri arasında yemeklik yağın önemli bir yeri vardır. Yemeklik yağ petrolden sonra en çok ithal edilen ürünler arasındadır. Türkiye bitkisel yağda net ithalatçı konumdadır. Eldeki mevcut yağın düşük fiyatla ihraç edilmesi yerine katma değeri yüksek bir şekilde iç pazarda yemeklik yağ olarak tüketilmesiyle bitkisel yağ ithalatında kısmi bir azalma sağlanabilir. Böylece cari açığın düşürülmesine olumlu yönde katkı sağlanırken ithal yağlara göre daha sağlıklı bir yağ olduğundan ülkenin sağlık harcamalarında da tasarrufa neden olabileceği düşünülmektedir.

Konunun paydaşlarının bir araya gelerek mevzuatta yapılacak ad değişikliği ile tüm bu olumlu katkıların önü kolaylıkla açılabilir. Ürünün adının zeytin püresi yağı olarak yeniden adlandırılmasıyla pazardaki mevcut markalar marka yayma kapsamında bu yeni ürünü pazara sürdüklerinde, tüketici talebiyle ürünün hak ettiği değeri bulacağı, böylece bu ürün nedeniyle ortaya çıkabilen tağşişin de önüne geçilmesiyle 
sektördeki haksız rekabetin kısmen engellenebileceği bir gerçektir. Çünkü pirina yağı bir zeytinyağ 1 türevi olduğu için diğer zeytinyağ tüketici aldatılabilmektedir.

Bu çalışmanın kısıtları arasına şunlar sayılabilir. Çalışma ürün için en uygun olduğu düşünülen sadece bir ad için yapılmıştır. Ürün için farklı adlar önerilirse bunların imaj farklılıkları paydaşlar arasında yapılacak araştırma ile belirlenebilir. Araştırma sadece tüketicileri kapsamaktadır. Konunun tüketiciler yanında tedarik zincirinin diğer üyelerini de içermesi olası eksiklikleri giderebilir.

\section{Kaynakça}

Aaker, D. A. (1991). Managing Brand Equity: Capitalizing on the Value of a Brand Name, The Free Press, New York (Aktaran, Woon, L.S., 2011).

Aaker, D. A. ve Keller, K. L. (1990). Consumer evaluations of brand extensions, Journal of Marketing, 54(1), 27-41.

Aime'- Garnier, I. ve Lai, C. (2008). Le changement de nom de marque: de'finition, clarification et proposition d'une typologie, De'cisions Marketing, 49, janvier-mars, 33-45. (Aktaran: Delassus ve Descotes, 2012).

Aimé-Garnier, I. ve Roux, E. (2006). Brand Name Changes: the Effect of Merging and Rupture Strategies on Consumer's Attitude Using the Social Representation Framework. Annual Conference of the European Marketing Academy, Athens, Greece.

Anderson, N. H. (1981). Foundations of Information Integration Theory, The Academic Press, New York.

Andrews, M. ve Kim, D. (2007). Revitalizing suffering multinational brands: an empirical study, International Marketing Review, 24(3), 350-372.

Bagozzi, R. P. ve Yi, Y. (1988). On the evaluation of structural equation models. Journal of the Academy of Marketing Science, 16(1), 74-94.
Bhat, S. ve Reddy, S. K. (2001). The impact of parental brand attribute associations and affect on brand extension evaluation, Journal of Business Research, 53(3), 111-122.

Biel, A. L. (1992). How brand image drives brand equity, Journal of Advertising Research, Nov/Dec, 9.

Bottomley, P. A. ve Holden, S. J. S. (2001). Do we really know how consumers evaluate brand extensions? Empirical generalizations based on secondary analysis of eight studies, Journal of Marketing Research, 38 (4), 494-500.

Bulut, E. ve Yllmaz, E. (2010). Comparison of the Frying Stability of Sunflower and Refined Olive Pomace Oils With/Without Adsorbent Treatment, JAOCS, Journal of the American Oil Chemists' Society, 87, 1145-1153.

Chakravarti, D., MacInnis, D. J. ve Nakamoto, K. (1990). Product perceptions, elaborative processing and brand name extension strategies, Advances in Consumer Research, 17, 910-916.

Chin, W. (1998). The partial least squares approach to structural equation modeling. In: Marcoulides, G.A. (Ed.), Modern Methods for Business Research, Lawrence Erlbaum Associates Publisher, Mahwah, New Jersey, 295-336.

Cobb-Walgren, C. J., Ruble, C. A. ve Donthu, N. (1995). Brand equity, brand preference, and purchase intent, Journal of Advertising, 24(3), 25-40.

Collange, V. (2008). The impact of brand name substitution on product evaluation and purchase intention, Recherche et Applications en Marketing, 23 (2), 1-17.

Collange, V. (2015). Consumer reaction to service rebranding, Journal of Retailing and Consumer Services, 22, 178-186.

Cronin, J.J ., Brady, M. K. ve Hult, G. T. M. (2000). Assessing the effects of quality, value, and customer satisfaction on consumer behavioral intentions in service environments, Journal of Retailing, 76 (2), 193-218. 
Czellar, S. (2003). Consumer attitude toward brand extensions: an integrative model and research propositions, International Journal of Research in Marketing, 20, 97-115.

Delassus, V. (2005). Strate'gie d'abandon de marque: analyse de transfert des valeurs de la marque abandonne'e vers la nouvelle marquee, the 'se de Doctorat en Sciences de Gestion, Universite' Lille 2, Lille. Aktaran: Delassus ve Descotes, 2012.

Delassus, V.P. ve Descotes, R.M. (2012). Brand name substitution and brand equity transfer, Journal of Product \& Brand Management, 21/2, 117-125.

Edell, J. A. ve Burke, M. C. (1986). The Relative Impact of Prior Brand Attitude and Attitude Toward the Ad on Brand Attitude After Ad Exposure. In Olson, J. and Stentis, K. (Eds), Advertising and Consumer Psychology, 3, 93-107.

Fishbein, M. ve Ajzen, I. (1975). Belief, Attitude, Intention and Behavior: An Introduction to Theory and Research, Reading, MA: Addison-Wesley.

Fishbein, M. ve Manfredo, M. J. (1992). A Theory of Behaviour Chang, In: Manfredo, M.J. Editor, (1992), Influencing Human Behavior: Theory and Applications in Recreation, Tourism and Natural Resources Management, Sagamore, Champaign IL, pp. 29-50.

Fornell, C. ve Larcker, D.F. 1981. Evaluating structural models with unobservables variables and measurement error, Journal of Marketing Research, 28, 39-50.

Gefen, D. ve Straub, D.W. (2003). A practical guide to factorial validity using PLS-graph: tutorial and annotated example, Communications of the AIS, 16, 91-109.

Gotsi, M. ve Andriopoulos, C. 2007). Understanding the pitfalls in the corporate rebranding process", Corporate Communications: An International Journal, Vo. 12 (4), 341-355.
Haig, M. (2003). Brand FAilures: The Truth About the 100 Biggest Branding Mistakes of All Time, Sterling, VA: Kogan.

Hair, J.F., Black, W.C., Babin, B.J. ve Anderson, R.E. 2010. Multivariate Data Analysis, 7e, Prentice Hall, Upper Saddle River.

Hair, J.F., Hult, G.T.M., Ringle, C.M. ve Sarstedt, M. 2014. A Primer On Partial Least Squares Structural Equation Modeling (PLS-SEM), SAGE Publications.

Hair, J.F., Sarstedt, M., Ringle, C.M. ve Mena, J.A. (2012). An assessment of the use of partial least squares structural equation modeling in marketing research, Journal of the Academy of Marketing Science, 40(3), 414-433.

Hellier, P.K., Guersen, G.M., Carr, R.A. ve Richard, J.A. (2003). Customer repurchase intention: A general structural equation model, European Journal of Marketing, 37(11/12), 1762-1800.

Hulland, J. (1999). Use of partial least squares (PLS) in strategic management research: A review of four recent studies. Strategic Management Journal, 20 (2), 195-204.

Jaju, A., Joiner, C. ve Reddy, S.K. (2006). Consumer evaluations of corporate brand redeployments. Journal of Academy of Marketing Science, 34 (Spring), 206-215.

Keller K.L. ve Aaker D.A. (1992). The effects of sequential introduction of brand extensions, Journal of Marketing Research, 24, 1, 35-50.

Keller, K.L. (1993). Conceptualizing, measuring and managing customer-based brand equity, Journal of Marketing, 57, 1-22.

Keller, K.L. (1999). Managing brands for the long run: brand reinforcement and revitalization strategies, California Management Review, 41 (3), 102-124. 
Keller, K.L. (2013). Strategic Brand Management: Building, Measuring, and Managing Brand Equity, 4e, Global Edition, Pearson.

Keller, K.L. (2003). Strategic Brand Management, 2e, Prentice Hall, Upper Saddle River.

Kotler, P. ve Armstrong, G. (2014). Principles of Marketing, 15e, Global Edition, Pearson, 255.

Kotler, P. ve Keller, K.L. (2012). Marketing Management, 14e, Pearson, 260.

Lacoeuilhe, J., (2000). L'attachement à la marque: proposition d'une échelle de mesure. Rech. Appl. Mark. 15(4), 61-77'den aktaran Collange, V., 2014.

MacKenzie, S.B., Lutz, R.J. ve Belch, G.E. (1986). The role of attitude the ad as a mediator of advertising effectiveness: a test of competing explanations, $\mathrm{JO}_{\mathrm{O}}$ urnal of Marketing Research, 23, 130-143.

Martin I.M. ve Stewart D.W. (2001). The differential impact of goal congruency on attitudes, intentions, and the transfer of brand equity, Journal of Marketing Research, 38 (4), 471-484.

Martin, G.S. ve Brown, T.J. (1991). In search of brand equity: the conceptualization and measurement of the brand impression construct. Proceedings of the AMA Winter Conference, 431-438.

Mitchell, A.A. (1986). The effect of verbal and visual components of advertisements on brand attitudes and attitude toward the advertisement, Journal of Consumer Research, 13, 12-24.

Muzellec, L. ve Lambkin, M. (2006). Corporate rebranding: destroying, transferring or creating brand equity?, European Journal of Marketing, 40 (7/8), 803-824.

Nasopoulou, C. ve Zabetakis, I. (2013). Agricultural and Aquacultural Potential of Olive Pomace A Review, Journal of Agricultural Science, 5 (7), 116-127.
Peter, J. P. ve Olson, J. C. (2010). Consumer behaviour \& marketing strategy, 9e, McGraw-Hill, International Ed.

Stuart, H. ve Muzellec, L. (2004). Corporate makeovers: can a Hyena be rebranded?, The Journal of Brand Management, 11 (6), 472-482.

Tenenhaus, M., Vinzi, V.E., Chatelin, Y.M. ve Lauro, C. (2005). PLS path modeling, Computational Statistics \& Data Analysis, 48, 159-205.

Thiele, R. S. ve Macky, M. M. (2001). Assessing the performance of brand loyalty measures, Journal of Service Marketing, 157, 529-546.

Ustaahmetoğlu, E., ve Toklu, İ.T. (2015). Organik gida satın alma niyetine tutum, sağlık bilinci ve gıda güvenliğinin etkisi üzerine bir araștırma, Ekonomik ve Sosyal Araștırmalar Dergisi, 11 (1), 197-211.

Völckner F. ve Sattler H. (2007). Empirical generalizability of consumer evaluation of brand extensions, International Journal of Research in Marketing, 24 (2), 149-162.

Woon, L.S. (2011). How customers assess rebranding strategy: The impact of perceived brand image similarity and loyalty before rebranding, M. Phil Thesis, The HK Polytechnic University.

www.dogusprina.com erişim 7.6.2015.

http://pirina.data-ist.com/ erişim 8.6.2015

http://www.internationaloliveoil.org/estaticos/ view/133-eu-producer-prices erişim 3.6.2015

http://www.internationaloliveoil.org/estaticos/ view/133-eu-producer-prices erişim 3.6.2015 